\title{
船体運動の統計的最適制御に関する研究 (2)
}

——制御則の解析——

正員 大 津 皓 平*

The Study on a Statistical Optimal Control of Ship's Motion (Part 2)

- Analysis of Control Law-

by Kohei Ohtsu, Member

\begin{abstract}
Summary
In the former report, the author analysed many sea trial's data under the AR autopilot system developed by the authors ${ }^{4}$. Emphasis of the report was mainly put on the evaluation of the course keeping quality.

The purpose of this paper is to analyse the same data from the view points of steering law subjecting to the AR autopilot system and the conventional system. One needs to have a robust method not influenced by an existence of feedback loops to attack such a complicated time series related mutually. An answer to this formidable problem is the multi-dimensional auto regressive model decision procedure proposed by Dr. Akaike.

The author proposes a new method to analyse actual ship trial data, gained at sea and uses it throughly.

He will report in this paper that such an analysis method, especially the noise contribution, the impulse response and the frequency response function calculated from the AR model give important informations to make clear the differences between the optimal steering law, the conventional autopilot steering one and a manual steering one.
\end{abstract}

\section{1 緒言}

著者は前報)において，小型練習船に装備した AR オ 一トパイロットによる最適保針制御を，種々の外乱下あ るいは種々のフィードバックゲイン下で評価した。それ らの結果は固定ゲインであるにもかかわらず比較的良い 結果を与えていた。

本報ではまず，前報に引き続き前報と同じデータを使 って最適操舵と従来の PID 操舵の操舵法自体の相違を 中心に解析する。

ところでこのような解析には，第 1 に舵がどのような 変数をどの範囲の周波数でどの程度フィードバックして いるかを調べる必要がある。第 2 に，その場合例えば Yaw のインパルス的変化に対し舵はどのように動いた か, あるいは周波数応答関数はどのような形となるか, などを実船で得られたデータから知る必要がある。

このよらな問題に対し従来から周波数領域でのアプロ 一チが確立していることはよく知られている8)。しかし 本方法は開ループ系の解析には有効であるが, 保針制御

* 東京商船大学航海学科
系の場合のように feedback の䜿った系の場合, 偏差が 生じ信頼性が落ちることもよく知られている1)。著者は 以前このような問題の解析には, 赤池によって提案され た多次元自己回㷌モデルによる時間領域からのアプロー チが良いことを指摘した2),7)。本報では全面的にこの赤 池による方法を駆使し, 前記第 1 の問題には従来のコヒ ーレンシー関数に変わって雑音寄与率の概念を, 第 2 の 問題には多次元自己回㷌モデルから得られるインパルス 応答関数・周波数応答関数を用いて解析する。

また，この方法を用いて得られた 2 隻の大型コンテナ 船のデータに対する若干の新しい結果昼を示し, Roll や プロペラ回転数に及ぼす操舵の影響についても言及す る。

\section{2 多次元自己回帰モデルよる統計的解析}

システムに入り达む有色な雑音 $u_{i}(n)$ によって駆動 される $k$ 次元フィードバック系が

$$
\begin{gathered}
x_{i}(n)=\sum_{j=1}^{k} a_{i j}(m) x_{j}(n-m)+u_{i}(n) \\
i=1,2, \cdots, k
\end{gathered}
$$


と線形インパルス表現できるとする。ここで $a_{i j}(m)$ は 入力変数 $x_{j}(n)$ から出力変数 $x_{i}(n)$ へのインパルス応 答関数とする。ただし， $a_{\imath \imath}(m)=0$ とする。

この線形モデルを多次元自己回帰モデル

$$
X(n)=\sum_{m=1}^{M} A(m) X(n-m)+W(n)
$$

に直す方法は既に述べた ${ }^{2)}$ 。ただし， $X(n)=\left(x_{1}(n), x_{2}\right.$ $\left.(n), \cdots, x_{k}(n)\right)^{T}, A(m)=\left\{A_{i j}(m)\right\}, W(n)$ はその要素 が白色雑音 $\varepsilon_{\imath}(n), i=1,2, \cdots, k$ からなるべクトル過程で ある。

インパルス応答関数との関係は,

$$
\left\{\begin{array}{c}
a_{i j}(1)=A_{i j}(1) \\
a_{i j}(m)=A_{i j}(m)+\sum_{l=1}^{m-1} A_{i i}(l) a_{i j}(m-l) \\
m=2,3, \cdots
\end{array}\right.
$$

である。

本報および前報において解析に用いている “雑音寄与 率 (Noise contribution)” は，次のように求められる。 まず，（2.1）をべクトル表示し

$$
X(n)=\sum_{m=1}^{M} A_{m} X(n-m)+U(n)
$$

とする。ただし $A_{m}=\left\{a_{i j}(m)\right\}, X(n)=\left(x_{1}(n), x_{2}(n)\right.$, $\left.\cdots, x_{k}(n)\right)^{T}, U(n)=\left(u_{1}(n), u_{2}(n), \cdots, u_{k}(n)\right)^{T}$ である。

雑音過程 $U(n)$ から $X(n)$ への閉ループ周波数応答 関数 $G_{c}(f)$ は,

$$
\begin{aligned}
G_{c}(f)=\frac{X(f)}{U(f)} & =\left(I-A_{m}(f)\right)^{-1} \\
& =\left\{\delta_{i j}(f)-a_{i j}(f)\right\}^{-1}
\end{aligned}
$$

で与えられる。ここで $A_{m}(f), X(f), U(f)$ は, $A_{m}$, $X(n), U(n)$ のフーリエ変換, $\delta_{i j}(f)=1(i=j), \delta_{i j}(f)$ $=0(i \neq j)$ とする $\left(a_{i i}(f)=0\right.$ に注意)。そこで $U(f)$ と $X(f)$ が, (2.5) すなわち

$$
X(f)=G_{c}(f) \cdot U(f)
$$

で結ばれているとき, $X(n)$ の $i$ 番目の要素 $x_{i}(n)$ の スペクトラムを求めてみる。(2.6) 式から， $g_{i j}(m)$ を $G_{c}(f)$ の要素の逆フーリエ変換とすると時間領域では, $g_{i j}(m)$ と $u_{j}(n-m)$ のたたみこみ演算, すなわち

$$
x_{i}(n)=\sum_{m=1}^{M} \sum_{j=1}^{k} g_{i j}(m) u_{j}(n-m)
$$

と書ける。これよりスペクトル計算に必要な $x_{i}(n)$ の自 己相関関数 $E\left[x_{\imath}(n) \cdot \overline{x_{\imath}(n-l)}\right]$ を求めるとき, 異なる $u_{i}(n), u_{j}(n), i \neq j$ に対して,

$$
E\left[u_{i}(n) \cdot \overline{u_{j}(n-l)}\right]=0
$$

が成立しておれば,

$$
\begin{aligned}
E & {\left[x_{i}(n) \cdot \overline{x_{i}(n-l)}\right] } \\
& =\sum_{m_{1}=1}^{M} \sum_{m_{2}=1}^{M} \sum_{j=1}^{k} g_{i j}\left(m_{1}\right) \cdot \overline{g_{i j}\left(m_{2}\right)} E\left[u_{j}\left(n-m_{1}\right)\right. \\
& \left.\overline{u_{j}\left(n-l-m_{2}\right)}\right]
\end{aligned}
$$

を得るので, $x_{i}(n)$ のパワースペクトラム $p_{i i}(f)$ は,

$$
p_{i i}(f)=\sum_{j=1}^{k}\left|g_{i j}(f)\right|^{2} p_{u_{j}}(f)
$$

によって与えられることがわかる。すなわち異なる $u_{i}(n), u_{j}(n)$ 間の相関がなければ, 要素 $x_{\imath}(n)$ 過程の パワースペクトラムは, $k$ 個の外乱 $u_{j}(n)$ のパロースペ クトラム $p_{u_{j}}(f)$ の $\left|g_{i j}(f)\right|^{2}$ による荷重和によって与 えられる $\left(p_{u_{j}}(f)\right.$ は, マトリクス $A(m)$ の対角項から 容易に求まる2),7)。

$$
q_{i j}(f)=\left|g_{i j}(f)\right|^{2} p_{u_{j}}(f)
$$

と拈くと, $q_{i j}(f)$ は周波数 $f$ に拈ける $x_{i}(n)$ のパワー スペクトラムのらちで, $u_{j}(n)$ の占める寄与部分を表 わし，

$$
r_{i j}(f)=\frac{q_{i j}(f)}{p_{i i}(f)}
$$

はその比率，

$$
R_{i j}(f)=\sum_{n=1}^{j} r_{i n}(f), \quad j=1,2, \cdots, k
$$

は, その累積比率を示す。（2.11）を, 以下では雑音寄 与率と呼び図示するには（2.13）を用いる。

最後に本報では周波数応答関数は, フィードバック系 であることを考慮して次のように求める。

まず，(2.3）のインパルス応答関数のフーリエ変換と して，それぞれのブロックの周波数応答関数

$$
\begin{gathered}
G_{i j}(f)=\sum_{m=1}^{M} a_{i j}(m) \exp (-i 2 \pi f m) \quad(2.14) \\
f=r / 2 L \Delta t, \quad i=\sqrt{-1}, \quad r=0,1, \cdots, L
\end{gathered}
$$

が計算できる。ただし，Lは周波数の分割数とする。

また, $i$ 変数の $j$ 変数に対する閉ループ周波数応答関 数 (closed loop frequency response function) $G_{c}(f)$ は,

$$
G_{c}(f)=\frac{G_{i j}(f)}{1-G_{i j}(f) G_{j i}(f)}
$$

によって与えられる（分母の負号に注意）。

\section{3 実船実験データの多次元 AR モデル による解析法}

前章で示した多次元 $\mathrm{AR}$ モデルによる時系列の統計的 解析法は，不規則な海洋波中で観測された定常な船体運 動時系列データの新しい解析法として有効であると考え られる。ここでは，次のような多次元 AR モデルによる 実船データの解析法を提案する1),7)。

（1）データの収集

本方法は統計学的には大標本論に属する。船のデータ では経験によると, サンプリング周期にもよるが大体 100 点以上はほしい。サンプリング間隔は, Aliasing を 起こさない程度に十分長くとるべきである。

（2） MAICE 法による多次元 AR モデルの決定 $k$ 次元 $\mathrm{AR}$ モデルを MAICE 法で決定する。このとき 


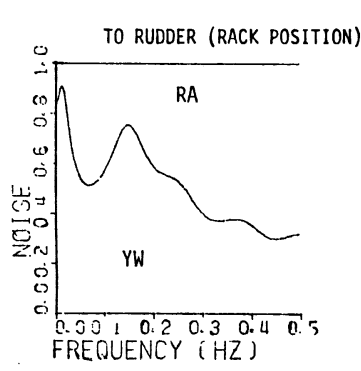

[A] $Q / R=20, T=0$
TO RUDDER (RACK POSITION)

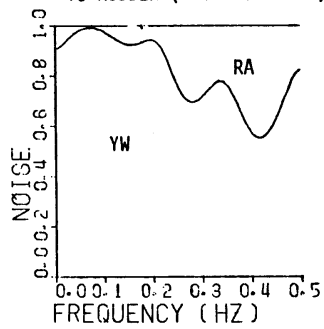

[B] $Q / R=160, T=0$
TO RUDDER (RACK POSITION)

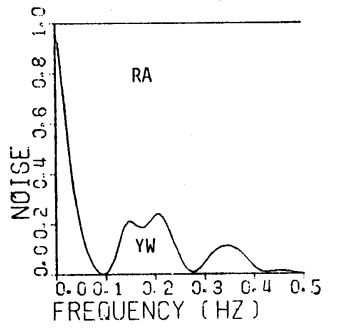

[C] PID

Fig. 1 Comparison of the noise contribution to rudder between the optimal and the PID steerings

[A] $Q / R=20$ (Optimal), [B] $Q / R=160$ (Optimal), [C] PID

$M$ 次モデルの AIC は, $N$ をデータ数， $\Sigma_{M}$ を予測誤差 の相関行列とすると，

$$
\operatorname{AIC}(M)=N \log \left\{\operatorname{det}\left(\Sigma_{M}\right)\right\}+2 k^{2} M \text { (3.1) }
$$

となる。また次数として想定する最高次数は $N / 3$ でき れば $2 \sqrt{N}$ までにとどめる。

\section{(3) スペクトラム解析}

スペクトラムの推定式は, 文献》に示したとおりであ る。ただし，個々の時系列のスペクトラム解析を行うた めには，(2) で求めた多次元 $\mathrm{AR}$ モデルからではなく, 1 時系列ずつ 1 次元 AR モデルを当てはめるべきであ る。また，この段階での Aliasing 現象のチェックなど は必要である。

\section{(4) 雑音寄与率の解析}

2 の方法に従って雑音寄与率を計算する。図化するに は累積比率（2.13）を使う表示がよい。ただし，この解 析が有効であるのは，(2) で多次元 AR モデルを当ては めたとさの各変数の予測誤差間の相関が低いことが条件 である ((2.8) 式)。

（5）インパルス応答, 周波数応答解析

インパルス応答関数を，(2.3）に従って計算する。各 ブロックの周波数応答関数は, (2.14)により, また閉ル 一プ周波数応答関数は（2.15）によって求める。閉ルー プ周波数応答関数は, (2.5) から求める方法もある ${ }^{1) ~ 3) 。 ~}$ 本法は特に制御系を設計する場合の変数の取捨選択, あるいは新しく設計した制御系の評価, 各船体運動モー ド間の連成の解析などに用いることが可能である。

\section{AR オートパイロットによる最適操 舵法の解析}

本章では, 前報4の汐路丸データを使って AR オート パイロットの最適操舵法と汐路丸搭載の従来型オートパ イロット（PID 型と呼ぶ）の操舵法との相違点を前章の 方法により比較検討する。

\section{1 雑音寄与率による解析}

前報 Fig. 13 は, Yaw への Rudder および Yaw 自身
の雑音の影響を示した図であった。逆に Rudder への Yaw および Rudder の影響を調べるには着目する変数 を Rudder にすればよい。それを示したのが Fig. 1 で， この図によって, 針路偏差のどの辺の周波数帯をどの程 度 feedback しているか知ることができる。そのうち, [A], [B] 図は $Q / R$ 比を 20 および 160 にしたときの 寄与率, [C]が PID の場合のそれである。前報の Fig. 10 (スペクトラム), Fig. 13 (雑音寄与率) をも参考に すると次のことが知れる。

(1) PID 型 ([C]図) では, Rudderから Rudder への寄与率が長周波の帯域を除き大きい。特に Rudder のスペクトラムのピークのある $0.1 \mathrm{~Hz}$ 付近の動きは自 分の起こした操舵に自分が応答している。このことは後 述するオートパイロット内のバックラッシュの影響を考 慮したとしても, 無駄な操舵が存在することを物語って いる。

（2）これに対し， [A], [B]の AR 型オートパイロ ットの場合をみると, Yaw からの feedback が $Q / R$ が 大きくなるほど広い帯域に広がっていることがわかる。 しかも前報の Fig. 13 の [A], [B] を見ると，その広い 帯域での動きが同図 [C]のように Yaw を逆に誘起す るよらな動きになって抢らず有効な操舵であるといえよ 5 。

\section{2 インパルス応答解析}

Fig. 2 は，上記データに対応する Yaw のインパルス 的変化に対する Rudder の応答を表わすインパルス応答 関数である。そのうち $[\mathrm{A}],[\mathrm{B}]$ 図は $Q / R=20,160$ に 対するもの，[C] は PID のものである。本図による と, $\mathrm{AR}$ 型の 2 例は, 初期舵の後にビートの残らない, 当て舵を効かした形となっているのに対し， [C]の PID 型ではビートが後まで残っている。また AR 型の場合, $Q / R$ を上げると初期の応答の強さが強くなっていること がわかる。AR 型のような形状のインパルス応答は一見 して PID 型でも微分を効かせば実現可能とみえるが, 実 際は困難である。 
なお参考のため，Fig. 3 に前図 Fig. 2[A]に対応する Rudder から Yaw ヘのインパルス応答関数を示す。図 からわかるように, 応答は不安定気味である。この原因 は，汐路丸のスパイラル試験成績など2),4) に現われた舵 角 $\pm 5^{\circ}$ 以内の異常現象から説明できる。すなわちこの データは前報のFig. 6 によると舵角量の標準偏差が 1

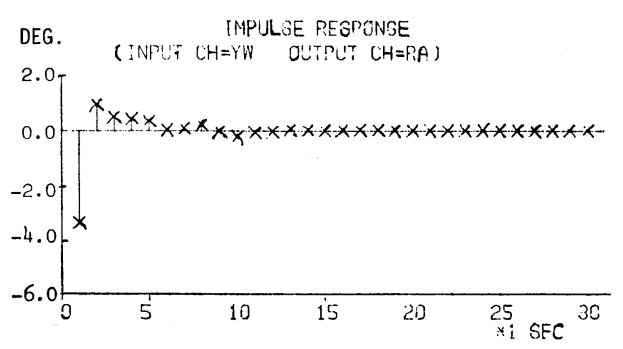

[A] $Q / R=120$ (AR steering)

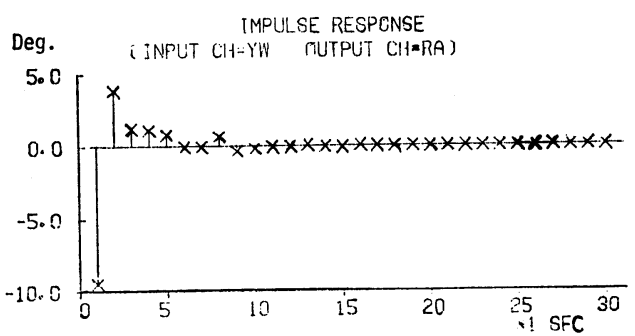

[B] $Q / R=160$ (AR steering)

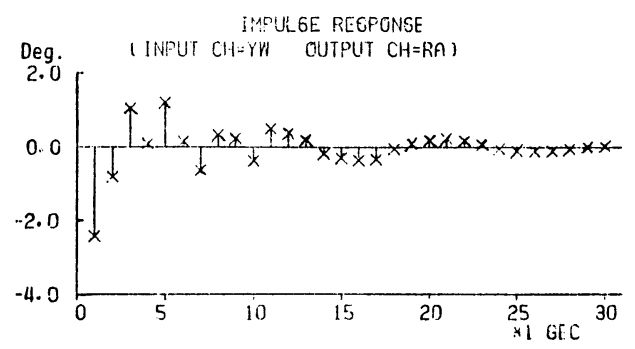

[C] PID steering

Fig. 2 Impulse response function from yaw to rudder

[A], [B] Optimal, [C] PID control

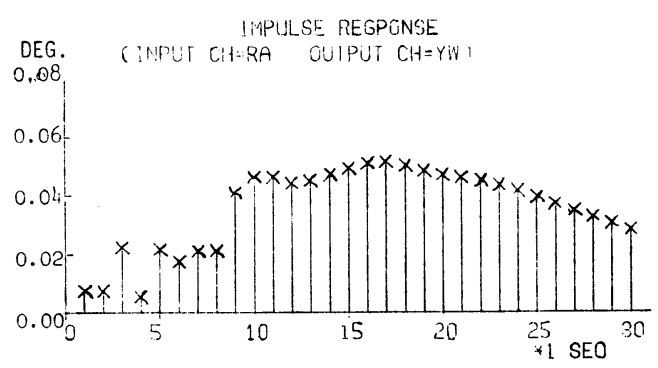

Fig. 3 Impulse response function from rudder angle to yaw in the optimal steering $3^{\circ}$ 以内であるが，この範囲は異常現象の範囲内に入って おり，インパルス応答にこのような影響が出ても不思議 ではない。

\section{3 周波数応答解析}

Fig. 4[A] は前報 Fig. 13 の AR オートパイロットデ 一タに対する (2.15) から求めた Yaw を入力とする Rudder の閉ループ周波数応答関数, Fig. 4[B]は対応 するPIDの場合のそれである。他のケースでも AR, PID ともに，ここで示したよらな形状を多くの場合示す。 1 本の矢印は $1 / 240 \mathrm{~Hz}$ に当たる。AR がほぼ平均的に各 周波数から feedback しているのに対し，PID の場合 $0.09 \sim 0.1 \mathrm{~Hz}$ 付近を特に重視している点が相違してい

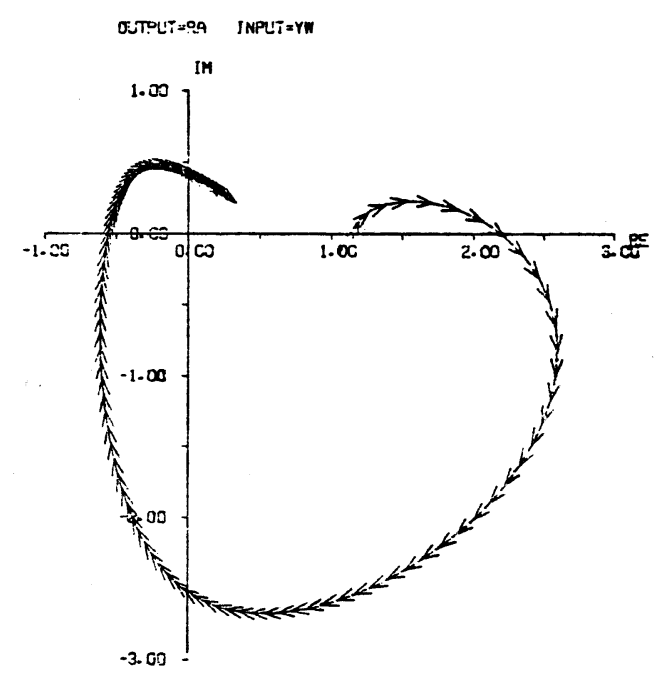

[A]

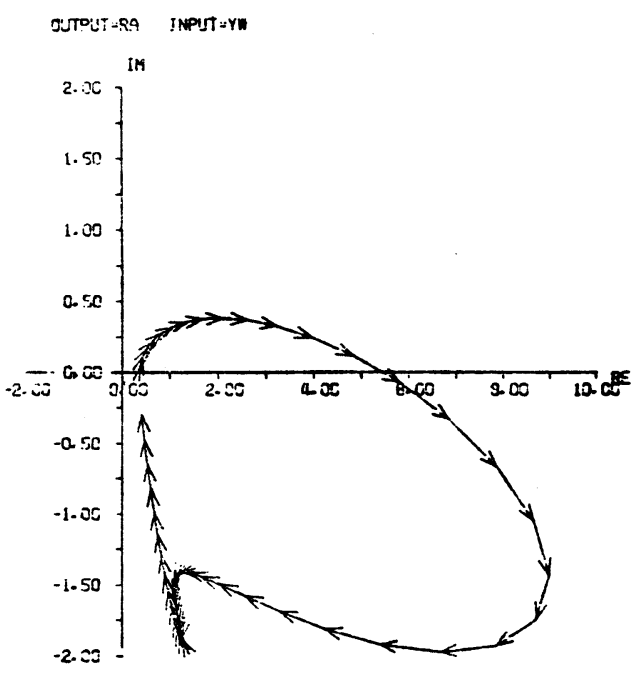

[B]

Fig. 4 Typical frequency response functions from yaw to rudder (closed loop) [A] Optimal, [B] PID steering 


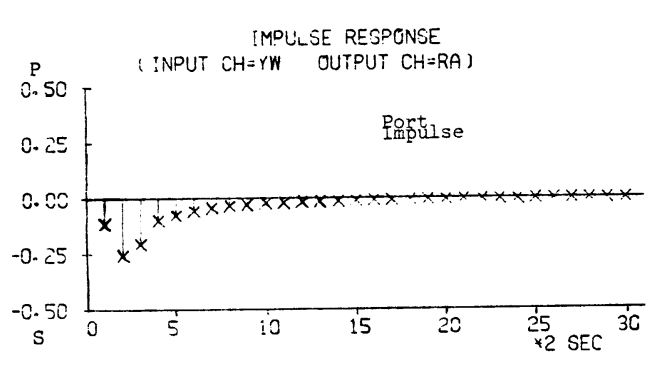

[A] Manual steering

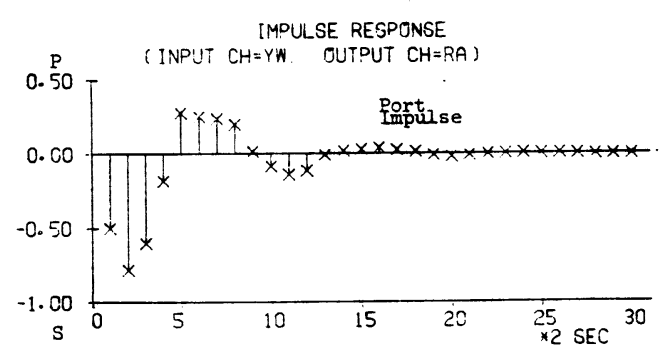

[B] Autopilot steering

Fig. 5 Impulse response functions from yaw to rudder in the America Maru data $(\Delta t=2 \mathrm{sec})$

る。

\section{5 大型コンテナ船の保針運動の解析}

4 で示したごとく，3で示した多次元自己回帰モデル による解析法は, 保針運動のように典型的な feedback 系の解析には効果的で信頼性の高い方法であることがわ かった。本章では, 汐路丸以外のデータとして，2隻の 高速コンテナ船の実船試験データに対して本方法を適用 して得られた保針運動に関する若千の 新しい知見を示 于5)。

\section{1 人間操舵と自動操舵}

著者は以前コンテナ船アメリカ丸データを使って， 4 のような操舵法の解析を行ったことがある2),3。しかし そこではサンプリング周期を $1 \mathrm{sec}$ とやや短く選びすぎ たため、インパルス応答などが観測雑音に污された結果 に終っている。今回サンプリング周期を $\Delta t=2 \mathrm{sec}$ とし て解析を行い好結果を得た。対象としたデータは, 以前 の報告 ${ }^{2), 3)}$ と同じく人間操舵 (No. 6) と自動操舵 (No. 10) データである。

Fig. 5[A], [B]は, Yaw のインパルス的変化に対す る操舵手 ( $[\mathrm{A}]$ 図), オートパイロット ( $\mathrm{B}]$ 図) の応 答を示すインパルス応答関数である。また Fig. 6[A], [B]は，(2.15）で求めた Yaw から Rudder への閉ル 一プ周波数応答関数である。図中 1 本の矢は $1 / 480 \mathrm{~Hz}$ である。波形，スペクトラム，雑音寄与率などは前の報 告2),3にある該当する図を参考にすればよい。

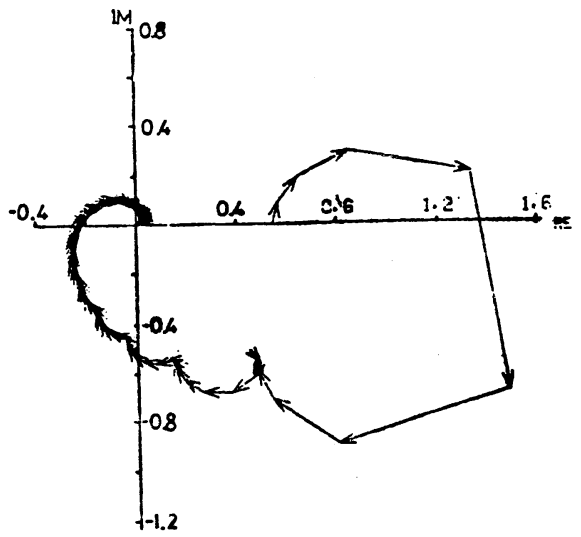

[A] Manual steering

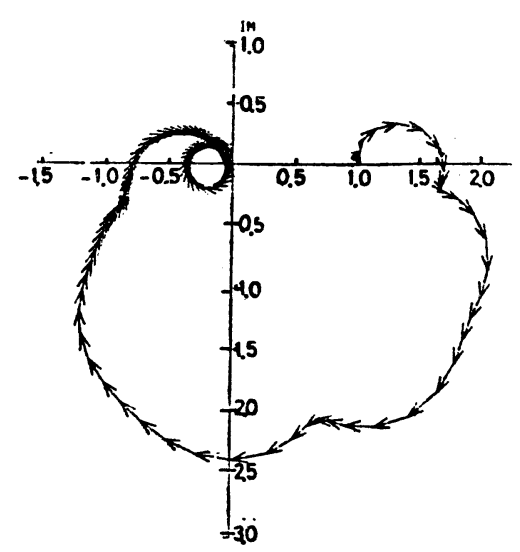

[B] Autopilot steering

Fig. 6 Frequency response function of rudder to yaw in the America Maru data ( $\Delta t$ $=2 \mathrm{sec}$ )

これらの図から，インパルス応答には，(1）人間操舵 は,このような荒海中では 1 次応答的になる (Fig. 5[A]) が，（2）自動操舵の場合は 2 次応答的となりビートが存 在する (Fig. 5[B])，などの特徴がみられる。

また，周波数応答関数には，(1) 人間操舵の場合, 長 周期の Yaw を多く feedback するため, 右方向に片膨 れしている (Fig.6[A]) のに対 し，（2）自動操舵の場 合は，(1)より平均的である (Fig.6[B])，（3）自動操 舵の場合, バックラッシュの影響で左上隅に渦巻きが見 られる (Fig.6[B])，などの特徽が指摘できる。

\section{2 操舵の Roll への影響}

前報4)でも，操舵による Roll 影響を指摘した。Fig. 7 は, アメリカ丸とは異なる排水量 3 万トンクラスの高速 コンテナ船の Head sea 中での Roll への雑音寄与率を 示したものである5)。変数は Yaw rate, Engine governor, Pitch, Roll, Z. acc., Propeller r.p.m, Rudder の 7 変数である $(\Delta t=2 \mathrm{sec}, N=500$ 点)。本例は本船が 
冬期北太平洋を Head sea および Follow sea の状態 で，自動操舵で航行中に得られた 30 例のデータの中か ら得られた代表例である。この 30 例を分けると, 特に 図のように Head sea 中で上記の現象がみられる。

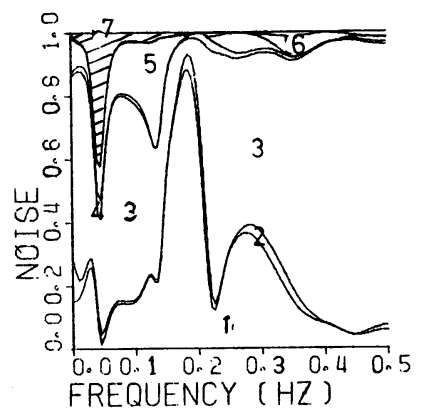

Fig. 7 Noise contribution to roll of a high speed container ship at head sea (1. Yaw rate 2. Governor 3. Roll 4. Pitch 5. Z. acc. 6. r.p.m.

7. Rudder (Hatching line))

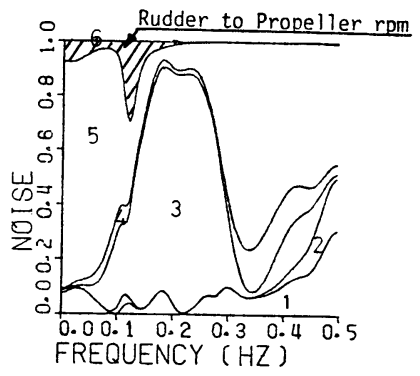

Fig. 8 Noise contribution to propeller r.p.m. of a high speed container ship at head sea

(1. Yaw rate 2. Roll 3. Pitch 4. Z. acc. 5. r.p. m. 6. Rudder (Hatching line))
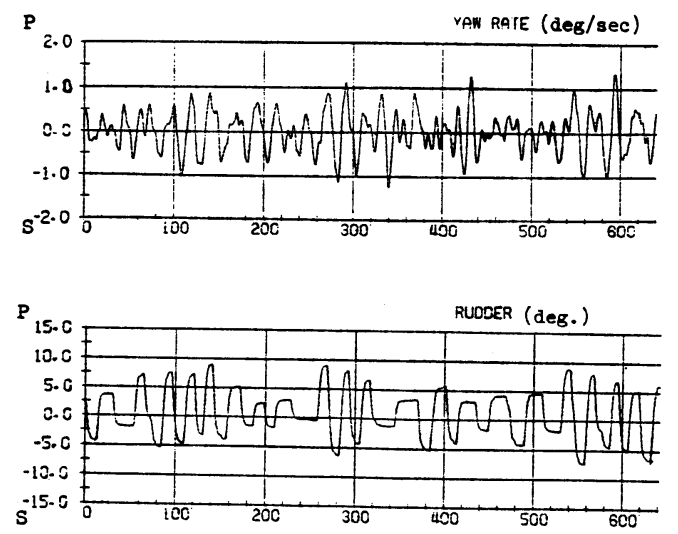

Fig. 9 Time series of yaw rate and rudder of a high speed container ship

\section{3 操舵の与えるプロペラ回転数への影響}

操舵することによりプロペラ回転数が変動することは よく知られている6)。

Fig. 8 は， 5.2 と同じ船のデータからこのことを調べ たもので, プロペラ回転数変動に対する舵角量を含めた 船体運動モードの雑音寄与率を示している5)。 図から操 舵がプロペラ回転数変動の一因となっていることが知れ る。

\section{4 バックラッシュの雑音寄与率への影響}

Fig. 9 は, 5.2, 5.3 で使ったデータの Yaw rate と Rudder の時系列の 1 例で, 明らかに自動操舵機構内の 天候調整の影響が認められる。Fig. 10, Fig. 11 は Yaw

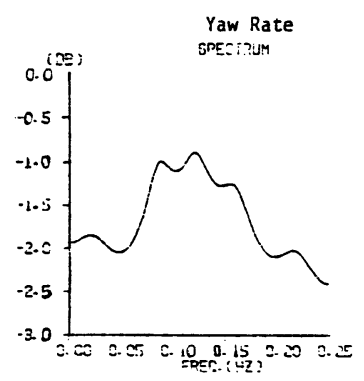

Fig. 10 Yaw rate spectrum

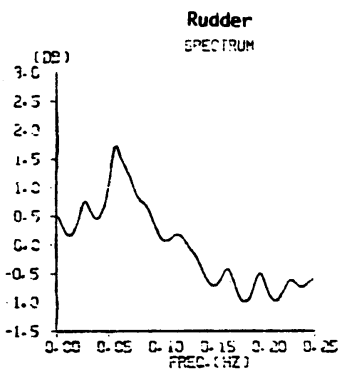

Fig. 11 Rudder angle spectrum

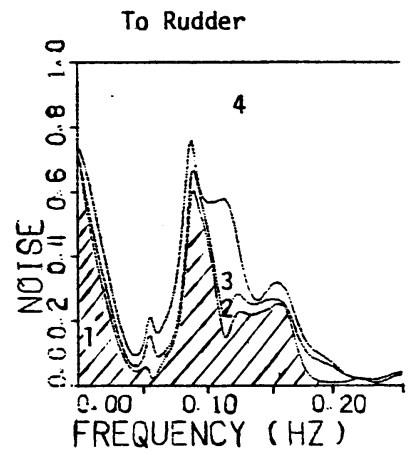

Fig. 12 Noise contribution to rudder

(1. Yaw rate 2.Pitch 3. Roll 4. Rudder The hatching line is yaw rate's contribution) 
rate と Rudder のスペクトラム, Fig. 12 は舵角への各 変数の雑音寄与率である。Fig. 12 を見ると, $0 \sim 0.03 \mathrm{~Hz}$ 間および $0.09 \mathrm{~Hz}$ より高い周波数にもら一つ Yaw rate から Rudder への feedbackがあり，両者の間に挾まれ た周波数帯での Yaw rate からの feedback は極めて低 い。ところが, Rudder のスペクトラムのピークは上記 範囲にあるが, Yaw rate のスペクトラムのピークはま さにその挾まった帯域にある。この原因は自動操舵内に あるバックラッシュにあることは, Fig. 9 の波形から容 易に見当がつく5。

このように雑音寄与率の解析を行うには, バックラッ シュなどの非線形要素に留意せねばならないことがわか る。

\section{6 結}

\section{言}

本報では前報りに引き続き $\mathrm{AR}$ オートパイロットによ る最適制御結果の解析を行った。そのらち今回は, 操舵 法を AR オートパイロットによる最適操舵, PID 操舵 法に分けそれぞれの操舵法の特色を統計的に明らかにす ることを試みた。そのため赤池による多次元自己回帰モ デルを使う新しい時間領域での解析法を提案し, このモ デルから得られる雑音寄与率, インパルス応答関数, 周 波数応答関数を応用し解析を行った。そその結果, 上記関 数特に雑音寄与率汇最適操舵と PID 操舵とで明らかな 相違がみられることを示した。このことを踏まえさらに 大型コンテナ船データに上の方法を適用し, 手動操舵と 自動操舵の相違, 操舵の与兄る Roll への影響, 操舵の 与えるプロペラ回転数への影響などを調べ若干の知見を 得た。
本報で用いた赤池の方法は，このように船船の新しい 制御系の設計時に起こる変数の選択の問題あるいは, 設 計されたシステムの再評価の問題に際し今後役立つもの と考えられる。

本稿を作成するに当たり東京大学 小山健夫教授に熱 心に議論していただいた。また，三井造船山内保文 氏, 統計数理研究所 赤池弘次氏, 北川源四郎氏, 本学 堀籠教夫氏には本テーマに対し全面的に協力をしていた だいた。これらの方々に深甚の謝意を表します。

\section{参考文 献}

1）赤池弘次, 中川東一郎：ダイナミックシステムの 統計的解析々制御, サイエンス社 (1972).

2）大津皓平, 北川源四郎, 堀籠教夫 : 保針運動の統 計的同定と最適操舵, 日本造船学会論文集, 第 139 号 (1976).

3）大津皓平, 半間俊士：自己回㷌モデルによる操舵 法の解析 (その 1 ), 日本航海学会論文集, 第 59 号 (1978).

4) 大津皓平：船体運動の統計的最適制御に関する研 究 (1), 日本造船学会論文集, 第 152 号 (1982).

5) 大津皓平：船体運動の統計的解析と最適操舵飞関 する研究, 東京大学学位論文 (1982).

6）平山伝治, 国分元宏, 岡村貞夫, 帆刈勇喜男: 実 船に扩ける推進動力測定, 船舶 (1983).

7) 山内保文, 大津皓平, 北川源四郎, 織田博行 : デ 一夕解析の動向 (2), 日本造船学会誌, 第 591 号 (1978).

8）山内保文：海洋波中の応答，耐航性に関するシン ポシウムテキスト, 日本造船学会 (1969). 